\title{
Trophic look at soft-bottom communities - Short-term effects of trawling cessation on benthos
}

\author{
Jennifer Dannheim ${ }^{\mathrm{a}, *}$, Thomas Brey ${ }^{\mathrm{a}}$, Alexander Schröder ${ }^{\mathrm{a}, \mathrm{b}}$, Katja Mintenbeck ${ }^{\mathrm{a}}$, Rainer Knust ${ }^{\mathrm{a}}$, Wolf E. Arntz ${ }^{\mathrm{a}}$ \\ a Alfred Wegener Institute Helmholtz Centre for Polar and Marine Research, Am Handelshafen 12, 27570 Bremerhaven, Germany \\ ${ }^{\mathrm{b}}$ Lower Saxony Water Management, Coastal Defence and Nature Conservation Agency, Germany
}

\section{A R T I C L E I N F O}

Article history:

Received 14 February 2013

Received in revised form 23 September 2013

Accepted 27 September 2013

Available online 9 October 2013

\section{Keywords:}

Trawling Impact

Trophic Functioning

Stable Isotopes

Energy Flow

Macrozoobenthos

North Sea

\begin{abstract}
A B S T R A C T
The trophic structure of the German Bight soft-bottom benthic community was evaluated for potential changes after cessation of bottom trawling. Species were collected with van-Veen grabs and beam trawls. Trophic position (i.e. nitrogen stable isotope ratios, $\delta^{15} \mathrm{~N}$ ) and energy flow (i.e. species metabolism approximated by body mass scaled abundance) of dominant species were compared in trawled areas and an area protected from fisheries for 14 months in order to detect trawling cessation effects by trophic characteristics. At the community level, energy flow was lower in the protected area, but we were unable to detect significant changes in trophic position. At the species level energy flow in the protected area was lower for predating/scavenging species but higher for interface feeders. Species trophic positions of small predators/scavengers were lower and of deposit feeders higher in the protected area. Major reasons for trophic changes after trawling cessation may be the absence of artificial and additional food sources from trawling likely to attract predators and scavengers, and the absence of physical sediment disturbance impacting settlement/survival of less mobile species and causing a gradual shift in food availability and quality. Our results provide evidence that species or community energy flow is a good indicator to detect trawling induced energy-flow alterations in the benthic system, and that in particular species trophic properties are suitable to capture subtle and short-term changes in the benthos following trawling cessation.
\end{abstract}

(C) 2013 Elsevier B.V. All rights reserved.

\section{Introduction}

Fishing, in particular bottom trawling, is one of the most severe anthropogenic impacts on marine environments (Dayton et al., 1995; Jennings and Kaiser, 1998; Thrush et al., 2001). Besides the removal of fish and bycatch, bottom trawling has two major impacts on benthic communities: (i) a direct physical effect that causes sediment disturbance and resuspension (Jennings et al., 2001b; Watling et al., 2001) as well as dislocation, damage and mortality of benthic organisms (e.g. Bergman and van Santbrink, 2000; Ramsay et al., 2000); and (ii) an indirect trophic impact through fishery bycatch and discards which become a significant additional food source for scavengers and predators (Arntz and Weber, 1970; Groenewold and Fonds, 2000; Rumohr and Kujawski, 2000). Long-term bottom trawling pushes benthic communities towards smaller, short-lived and fast growing species. After at least five decades of intense trawling in the North Sea (Lindeboom and de Groot, 1998; Rijnsdorp et al., 1998) changes add up to a shift from high to low diversity and from a high biomass-low turnover to a low biomasshigh turnover system (Callaway et al., 2007; Hiddink et al., 2006a; Kaiser et al., 2002).

\footnotetext{
* Corresponding author at: Alfred Wegener Institute Helmholtz Centre for Polar and Marine Research, Am Handelshafen 12, 27570 Bremerhaven, Germany. Tel.: +49 47148311734. E-mail address: jennifer.dannheim@awi.de (J. Dannheim).
}

Particularly in coastal zones with a long fishing history it is difficult but not impossible to identify distinct and persistent effects of bottom trawling (De Juan et al., 2007; Gray et al., 2006; Thrush and Dayton, 2002), as long-term frequent trawling might have created a highly artificial benthic system with a trophic structure which is resistant against environmental stressors (Jennings et al., 2001a; Menge and Sutherland, 1987; Yachi and Loreau, 1999). Moreover, shallow coastal marine systems can be extremely dynamic in terms of hydrographic conditions. Abundance, biomass and species inventory are shaped by seasonal and year-to-year variability, governed by and adapted to abiotic and biotic forcing factors (Clark and Frid, 2001; Kröncke et al., 2001). Last not least, bottom trawling itself creates variability by an uneven distribution of trawling impact in space and time (e.g. Rijnsdorp et al., 1998). Hence, artificial robustness of the benthic system and statistical "noise" are principal problems of studies on trawling effects in shallow water systems, particularly in sandy habitats, but see e.g. Cranfield et al. (1999), Wolff (2005) and Reise (2005) as examples for distinct trawling effect on mussel beds in dynamic environments.

Biological traits of the constituting species (e.g. Collie et al., 2005; Tillin et al., 2006), species trophic properties and species-dependent trophic properties (e.g. energy flow patterns) are of particular significance to detect trawling effects. Several studies of the last decade, therefore, focused on changes in habitat complexity (e.g. levelling habitat structure along with species loss, see Thrush et al., 2001; Thrush and 
Dayton, 2002), on community size spectra, trophic positions and derived energy flow patterns (Hiddink et al., 2006a; Jennings et al., 2001b, 2002a), as well as on benthic community functioning as indicated by biological trait composition (e.g. Blanchard et al., 2004; Tillin et al., 2006). Previous studies of trawling effects on trophic structure suffered from methodological problems: they either compared subsystems only, such as fish communities (e.g. Badalamenti et al., 2002) and/or lacked appropriate untrawled reference sites (e.g. Jennings et al., 2001a, 2002b). However, working at coarser systematic resolution (e.g. feeding guilds) might not be sufficient to capture subtle and/or short-term changes (e.g. within a few years; see Queirós et al., 2006; Tillin et al., 2006).

Hence, trophic properties at the species level might be more sensitive to detect effects of trawling. On the one hand, many ecological studies provided evidence that trawling does not only cause direct mortality, but also alters the physical and biogeochemical composition of the sediment and causes trophic distortion by food input (discards and gear-induced mortality) which, finally, affects the benthic ecosystem to a certain extent as a whole (Jennings and Kaiser, 1998; Malakoff, 2002). On the other hand trophic interactions between organisms are an important basis of ecological functioning (Cohen, 1978; May, 1974; Pimm, 1982), and these interaction patterns entail communities' ability to cope with perturbations (e.g. Dunne et al., 2002).

The construction of the research platform FINO 1 in the German Bight (North Sea) and the concurrent closure of the site for fishery in the year 2003 provided for the first time the opportunity to compare the development of benthic communities at one protected site and further trawled sites in the German Bight. In this study, we investigate whether changes in the trophic structure of a shallow sand-bottom community after cessation of trawling can be measured based on species trophic properties (e.g. trophic position: species vertical trophic position within the trophic hierarchy) and species-dependent trophic properties (e.g. energy-flow pattern). We evaluate whether these trophic properties are suitable to detect trophic alterations (e.g. trophic distortion and sediment biogeochemistry changes) after short-term closure (only 14 months) of fishery.

\section{Material and methods}

\subsection{Study site}

In July 2003, the research platform FINO 1 was built as a pilot project for future offshore wind farms. The platform is located at $28 \mathrm{~m}$ water depth in the German Bight, $45 \mathrm{~km}$ off the Island Borkum (Fig. 1). The surroundings of the platform (500 m radius) are closed for all shipping activities (except scientific activities) and are thus protected from fisheries (for further details see Dannheim, 2007).

Beam trawling is the predominant type of fishery in this part of the German Bight, targeting sole (Solea solea) and plaice (Pleuronectes platessa). Seasonal patterns in trawling intensity are attributed to seasonal migration of target fish stocks (see Pastoors et al., 2000; Piet and Rijnsdorp, 1998). To estimate the impact of trawling in the study area, trawling intensity was calculated by means of the satellite-based "Vessel Monitoring System" for the main operating fleets (VMS-data for Dutch and German fleet; unpublished data provided by S. Ehrich, Federal Research Centre for Fisheries and by G. Piet and F. Quirins, Netherlands Institute for Fisheries Research). Trawling intensity was calculated as times trawled month ${ }^{-1}$ (i.e. $\times \operatorname{spot}^{-1}$ ) following Rijnsdorp et al. (1998). There were no spatial trends or differences in trawling intensity detectable between the study sites prior to closure, i.e. seasonality is the major determinant of trawling intensity (Fig. 2, see Schröder and Dannheim, 2006).

Sampling areas (Fig. 1) were defined as follows: The "protected area" (hereafter referred to as PA) comprised the zone between an inner circle of $150 \mathrm{~m}$ radius and an outer circle of $400 \mathrm{~m}$ radius around the platform, i.e. an area of about $0.43 \mathrm{~km}^{2}$. These distances from the

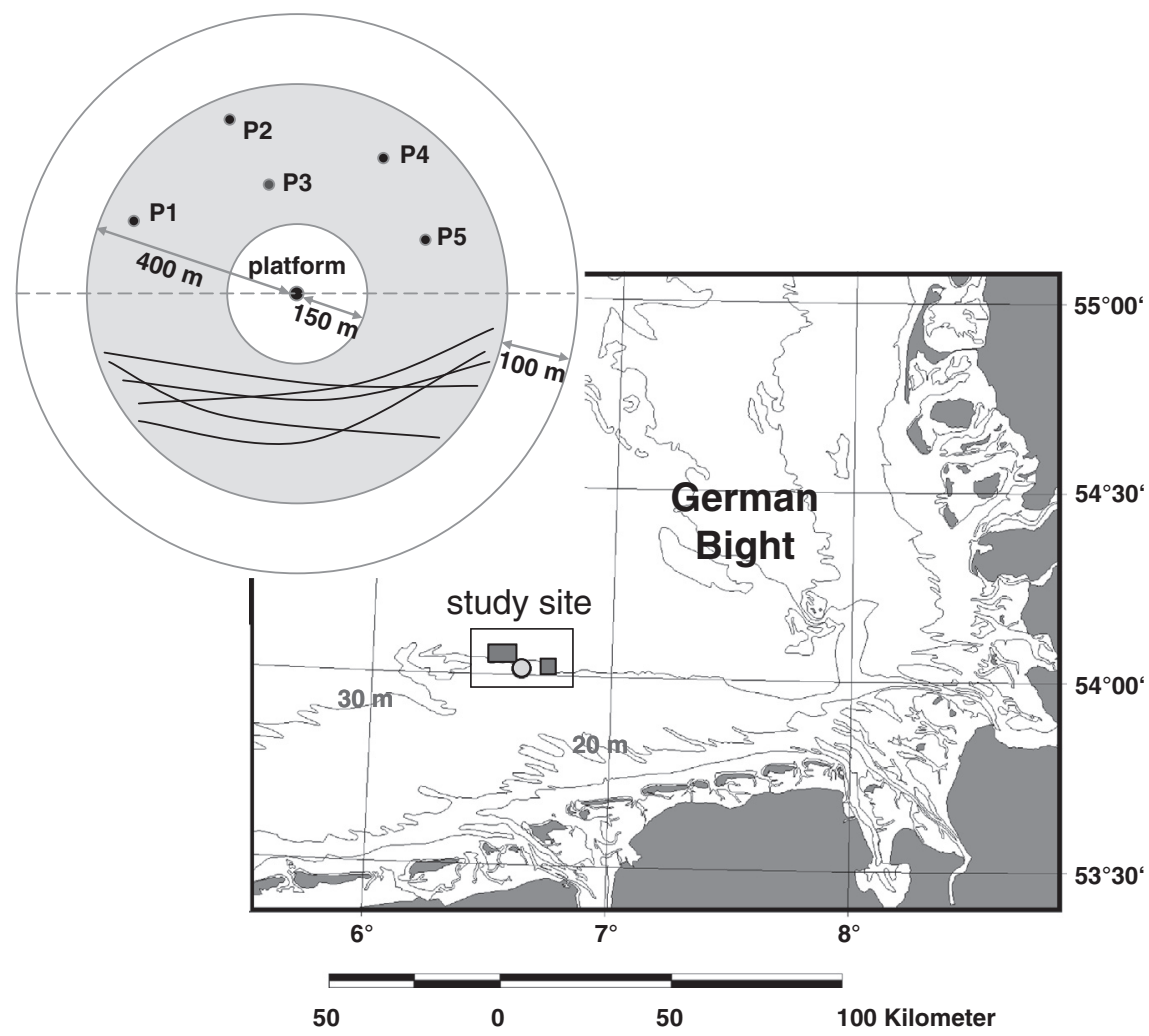

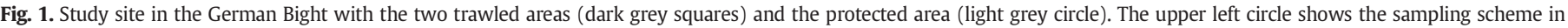

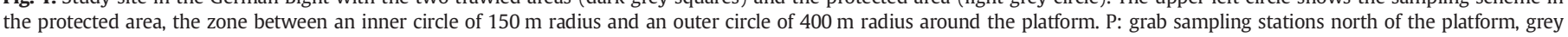
lines: exemplary beam-trawl tracks south of the platform. 


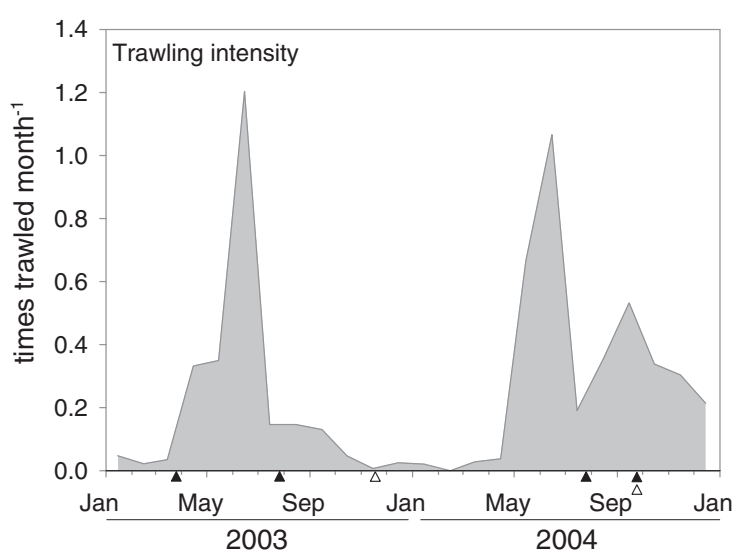

Fig. 2. Trawling intensity (times trawled month ${ }^{-1}$ ) for the trawled area during the study period. Black triangles mark dates of pre-closure sampling in March and July/August 2003 ( 3 months before and 2 weeks after closure) and post-closure sampling in July/August and September/October 2004 (12-14 months after closure). White triangles mark dates of sampling for stable isotope analyses.

platform itself and from the border of the protected area were kept to minimise edge effects caused by the construction and by the surrounding trawled area. Effects of the platform construction on the fauna and the sediment structure or biogeochemistry can be excluded: contemporaneously to our study, Joschko (2007) confined platform effects on the soft-bottom community to a narrow range of less than $17 \mathrm{~m}$ and Schröder et al. (2008) limited effects of an increase in organic enrichment caused by the hard-bottom community of the platform to a range of less than $100 \mathrm{~m}$. Two zones beyond the $500 \mathrm{~m}$ radius, $9 \mathrm{~km}$ apart from the protected area in north-western and eastern direction $\left(25\right.$ and $\left.5 \mathrm{~km}^{2}\right)$ were chosen as reference sites. Data of the two reference sites were pooled as the zones did not differ statistically in species composition, abundance and biomass (PRIMER, analysis of similarity (ANOSIM); abundance: $R=0.15, p=0.08$; biomass: $R=0.12, p=0.10$ : for further details see Dannheim, 2007). Hence, the pooled reference sites are hereafter referred to as the "trawled area" (TA). Larger area (TA) may increase spatial heterogeneity and thus statistical variability among replicate samples. However, variances did not differ between samples (see Section 2.5) taken in PA and TA for community analysis. Hydrographic conditions are identical in PA and TA, as the prevailing strong tidal currents $\left(\leq 1 \mathrm{~m} \mathrm{~s}^{-1}\right)$ displace the water masses over far larger scales than the study area.

\subsection{Sampling and sample treatment}

In both areas, PA and TA, sampling of the benthic community was carried out with "RV Heincke" during 2 periods. The first sampling period, defined as "pre-closure", includes two sampling campaigns: one campaign 3 months before and one campaign 2 weeks after fishery closure of PA (March/April and July/August 2003). "Post-closure" sampling was also carried out in two campaigns: one campaign in July/August and one campaign in September/October 2004, i.e. 1214 months after fishery closure of PA. In PA, epifauna, infauna and sediment samples were taken at 5 stations during each of two sampling campaigns (pre-closure: 2 campaigns $\times 5$ stations $=10$ stations, postclosure: 2 campaigns $\times 5$ stations $=10$ stations). In TA, samples were taken at 5 stations in each of the two pre-closure campaigns (preclosure period: 2 campaigns $\times 5$ stations $=10$ stations) and at 9 stations in each of the two post-closure campaigns (post-closure period: 2 campaigns $\times 9$ stations $=18$ stations). Pre-closure and post-closure samples from both sampling dates show seasonal effects (ANOSIM pre-closure PA and TA: $p<0.01, R=1.0$ for abundance and biomass; post-closure PA and TA: $p<0.01, R=0.8$ and 0.7 for abundance and biomass; for further details see Dannheim, 2007). However, for this study, the seasonality in fishing intensity is deemed more significant than natural seasonal forcing. Hence, we pooled the samples in the pre-closure period and post-closure period, respectively, to cover the time of high fishing intensity in both periods (see Fig. 2). Thus, the sampling design is based on 48 stations: 20 from PA (10 pre-closure, 10 post-closure) and 28 from TA (10 pre-closure, 18 post-closure).

Infauna was sampled with a $0.1 \mathrm{~m}^{2}$ van Veen grab (95 kg). Samples were taken exclusively in the area north of the platform (see Fig. 1; 3 replicates per station, see Dannheim (2007) for variability of numerical parameters). Grab content was sieved on $1 \mathrm{~mm}$ mesh size and fixed in $4 \%$ buffered formalin. At each station 2 surface sediment samples (5-6 cm, not stratified) were collected from the first grab with 5 and $2 \mathrm{~cm}^{3}$ PVC corers. Samples were stored at $-20^{\circ} \mathrm{C}$ until further analysis.

Epifauna was sampled with a beam trawl ( 3 m opening width, codend mesh size: $1 \mathrm{~cm}$, haul duration: $\leq 10 \mathrm{~min}$ at 3 knots, towed distance PA: $599 \pm 114$ m, TA: $888 \pm 234$ m, see Dannheim (2007) for variability of numerical parameters). Trawled distance at the bottom was determined by Differential Global Positioning System (DGPS). Hauls in PA were restricted to the part south of the platform in order to avoid selfmade trawling disturbance at the grab stations (see Fig. 1). Epifauna subsamples from each catch were stored frozen at $-20^{\circ} \mathrm{C}$ until further treatment.

Sampled specimens were identified to the lowest possible taxonomic level. Species abundance and biomass from grab and beam-trawl samples were standardised to $1 \mathrm{~m}^{2}$ and pooled for each station. Species wet biomass ( $\mathrm{mg} \mathrm{m}^{-2}$ ) and average body mass $(\mathrm{M}, \mathrm{mg}$ ) were converted to kilo Joule (kJ) by conversion factors taken from Brey (2001).

From additional grab and trawl samples, 464 specimens of the 23 most abundant species (PA: 181/22; TA: 283/22, species size range was similar in PA and TA) were collected for stable nitrogen isotope analysis during a cruise in November 2003 (samples only from TA) and the post-closure cruise in September/October 2004 (samples from $\mathrm{TA}$ and PA). Individuals were sorted directly on board and stored at $-20{ }^{\circ} \mathrm{C}$ until further treatment (whole organisms, exceptions: see further discussion). In small bodied species (Euspira pulchella, Poecilochaetus serpens, Spiophanes bombyx, and Urothoe poseidonis), several individuals were pooled to achieve the minimum sample size ( $>5 \mu$ g nitrogen) required for sufficient precision in isotopic measurements. In large bodied species, only muscle tissue was sampled (Liocarcinus holsatus, Pagurus bernhardus, Asterias rubens, and Astropecten irregularis). Gut contents of whole organisms were not removed prior to sample freezing. Generally, this might lead to lower nitrogen isotope values in whole organisms compared to samples of extracted muscle tissue (Peterson and Fry, 1987, but see Mateo et al., 2008). However, we do not expect effects on our conclusions because comparisons (pre-post, PA-TA; see Section 2.5) were not made between different species, but only between equally treated conspecifics from different areas. Upon return to the laboratory, frozen tissue samples were lyophilised for $24 \mathrm{~h}$ (Finn-Aqua Lyovac GT2E), homogenised in a ball mill and treated with $1 \mathrm{~mol}^{-1}$ hydrochloric acid $(\mathrm{HCl})$ according to Jacob et al. (2005) to ensure comparability of isotope data between studies, independently of species carbonate content. Subsequently, samples were dried again at $55{ }^{\circ} \mathrm{C}$ and ground to powder in a mortar prior to analysis. Mass-spectrometric measurement of stable nitrogen isotope composition was carried out in the GeoBioCenter ${ }^{\mathrm{LMU}}$, University of Munich (Thermo/Finnigan Delta Plus). Current gaseous standards for calibration were used. Experimental precision was better than $\pm 0.2 \%$.

\subsection{Sediment parameters}

Sediment fractions were determined by wet and dry sieving of the larger sediment sample $\left(5 \mathrm{~cm}^{3}\right)$ with a sonic sifter (ATM) over a Wenthworth scaled standard sieve set (Wenthworth, 1922), silt and clay fraction $(\%<63 \mu \mathrm{m})$ was determined and median grain size (MdGS, $\mu \mathrm{m})$ was calculated. The smaller sample $\left(2 \mathrm{~cm}^{3}\right)$ was freezedried and homogenised in a mortar. Nitrogen and carbon content $(\% \mathrm{~N}$, $\% \mathrm{C}, \mathrm{C} / \mathrm{N}$ by mass) were determined with an elemental analyser (LECO 
CNS-2000). Inorganic carbon was removed by adding $12 \mathrm{~mol} \mathrm{l}^{-1} \mathrm{HCl}$ to an additional subsample to determine $C_{\text {org }}$ content (LECO CS-125). Mahalanobis jackknife distances (Barnett and Lewis, 1994) identified one multivariate outlier in the sample space [MdGS, $\%<63 \mu \mathrm{m}$, $\% \mathrm{~N}, \% \mathrm{C}, \mathrm{C}_{\mathrm{org}}$, and $\left.\mathrm{C} / \mathrm{N}\right]$ which was excluded from further analyses (remaining data $\mathrm{N}=47$ ). Differences in sediment parameters between areas (PA, TA) were tested by two-way analysis of variance (ANOVA) and one-way ANOVA for data available only from one sampling period. Therefore, sediment parameters were checked for normality (Kolmogorov-Smirnov test) and homogeneity of variances (Bartlett's test) and parameters expressed as percentages $(\%<63 \mu \mathrm{m}$, $\% \mathrm{C}, \% \mathrm{~N}$, and $\% \mathrm{C}_{\mathrm{org}}$ ) were arcsine-transformed.

\subsection{Trophic parameters}

Two trophic parameters were applied to compare the trophic structure in PA and TA: trophic position and energy flow.

\subsubsection{Trophic position}

The tissue stable nitrogen isotope ratio $\left({ }^{15} \mathrm{~N} /{ }^{14} \mathrm{~N}=\delta^{15} \mathrm{~N}\right)$ is a proxy of an organism's position within the trophic hierarchy of an ecosystem. With each assimilation step along the food chain, the heavier isotope ${ }^{15} \mathrm{~N}$ becomes enriched in consumer tissues owing to an enzymatic selection. Fractionation of ${ }^{15} \mathrm{~N}$ results in a $\delta^{15} \mathrm{~N}$ increase ranging from 1.4 to 3.4\% per trophic level (e.g. McCutchan et al., 2003; Post, 2002). According to Yodzis (1984) and Cohen et al. (2003), we define trophic position $\mathrm{TP}_{i}$ of species $i$ by

$T P_{i}=\delta^{15} \mathrm{~N}_{i}[\% \circ]$.

We measured the trophic positions of 23 species. Species with a sufficient number of replicates (20 species) were used for the analysis of species trophic characteristics (post-closure data only, see Section 2.5.2). Analysis of community trophic characteristics (Section 2.5.1) required trophic positions of all species involved. We used our own data on 23 species from pre-closure and post-closure samplings. For each species, we tested for differences in trophic position between sampling dates (pre, post) by one-way ANOVA, after the data had been tested for normality (Kolmogorov-Smirnov test) and homogeneity of variances (Bartlett's test). Since $\delta^{15} \mathrm{~N}$ values did not vary within species between pre-closure and post-closure samplings data from both sampling dates were pooled. Trophic positions for the remaining 183 species encountered in the sampling areas (PA and TA) were estimated indirectly: from published and unpublished sources, we collected $\delta^{15} \mathrm{~N}$ data of species which were taxonomically and geographically as close as possible (for $\delta^{15} \mathrm{~N}$ data sources see Supplementary material). To account for between-systems differences in $\delta^{15} \mathrm{~N}$, we adjusted all data by the difference in $\delta^{15} \mathrm{~N}$ of the primary food source (POM, particulate organic matter) between the German Bight, $G B$ (our data, water sample at $5 \mathrm{~m}$ depth, POM $=6.07 \%$ ), and the corresponding other systems (OS) i.e.

$T P_{i}=\delta^{15} \mathrm{~N}_{i}+\left(\delta^{15} \mathrm{~N}_{\mathrm{POM}, G B}-\delta^{15} \mathrm{~N}_{\mathrm{POM}, \mathrm{OS}}\right)[\% \mathrm{o}]$.

When $\delta^{15} \mathrm{~N}$ of primary consumers $(P C$, representing the food-web bottom line; Vander Zanden and Rasmussen, 1999) and not of POM was given as a baseline, we used

$T P_{i}=\delta^{15} \mathrm{~N}_{i}+\left(\delta^{15} \mathrm{~N}_{P C, G B}-\delta^{15} \mathrm{~N}_{P C, O S}\right)[\%$ o]

accordingly (see Supplementary material for $P C \delta^{15} \mathrm{~N}$ values, species marked with an asterisk). We used our own data from 11 out of 23 species to adjust $\delta^{15} \mathrm{~N}$ of species taken from the mentioned published and unpublished sources. Care was taken that only data were used from studies that applied comparable lab procedures (see Supplementary material for $\delta^{15} \mathrm{~N}$ sources). The mean variation between $\delta^{15} \mathrm{~N}$ from other sources and from our measurements was $1.03 \%$. To each species, only one mean $\delta^{15} \mathrm{~N}$ value was assigned. Variation in community trophic characteristics (see Section 2.5.1) between PA and TA before and after closure to fishery can thus only arise from variation of the qualitative and quantitative community composition. In cases where we were not able to find $\delta^{15} \mathrm{~N}$ data from sufficiently close relatives, we assigned the average $\delta{ }^{15} \mathrm{~N}$ value of the appropriate feeding guild (for feeding guilds and corresponding literature see Supplementary material) to a species. Parasites (Vitreolina philippi and Turbonilla acuta) were excluded from analyses ( 7 individuals).

\subsubsection{Energy flow}

Energy flow through a particular population is related to abundance and average body size because metabolic rate scales with body size by an exponent of about 0.75 (rate $=a * M^{0.75}$, see West and Brown (2005) for the general validity of the scaling factor 0.75 ). We define the energy flow of a species as its contribution to overall community energy flow. Therefore, energy flow $E F_{i}$ of species $i$ is approximated by

$E F_{i}=N_{i} * M_{i}^{0.75}\left[\mathrm{~kJ} \mathrm{~m}{ }^{-2}\right]$

where $N_{i}$ and $M_{i}$ are the abundance and mean body mass of species $i$ respectively. Overall community energy flow $E F_{\text {com }}$ is estimated accordingly by

$E F_{\text {com }}=\sum_{i=1}^{n}\left(N_{i} * M_{i}^{0.75}\right)\left[\mathrm{kJ} \mathrm{m}^{-2}\right]$

where $n$ is the number of species. These parameters were computed for each sample (each grab and beam-trawl station) separately.

We applied two different indices, (i) absolute energy flow $E F_{i}$ (comparable to a scaled abundance) as described previously, and (ii) relative energy flow $R E F_{i}$ that describes the contribution of species $i$ to community energy flow $E F_{\text {com }}$ (i.e. comparable to a measure of species dominance within a community)

$R E F_{i}=100 * E F_{i} / E F_{\text {com }}[\%]$

where 'com' refers to the community of TA and PA, respectively.

\subsection{Trophic analyses}

Two kinds of trophic analysis were performed to compare the trophic structure in PA and TA: community and species trophic characteristics. For community trophic analysis, we used own and literature TP data, while we used only our own TP data (post-closure measurements, 20 species) for species trophic analysis.

\subsubsection{Community trophic characteristics}

Trophic position frequency distributions (TPFD) were used to compare community trophic structure (based on literature and own TP data) between areas, before and after cessation of trawling. A TPFD identifies the distribution of species energy flow $\left(E F_{i}\right)$ over the trophic position range $\left(\delta^{15} \mathrm{~N}\right)$ of the community. We assigned one mean $\delta^{15} \mathrm{~N}$ value to each species for the TPFD approach. Therefore, variation in TPFD between areas (PA-TA) and closure (pre-post) can only develop from the qualitative and quantitative community composition. Differences in TPFD (i.e. shape of frequency distribution over trophic positions) versus area (PA, TA) and closure (pre-post) were tested by pairwise median rank tests (rank sums, $p<0.05$ ).

Community energy flow $\left(E F_{\text {com }}\right)$ was calculated for TA and PA prior to closure of the fishery (March and July/August 2003, $N=10$ samples in TA and PA, each) and 1 year after closure (July/August and September/ October 2004, N=18 and 10 samples in TA and PA, respectively). Data were checked for normality (Kolmogorov-Smirnov test) and homogeneity of variances (Bartlett's test). Significant differences of 
$E F_{\text {com }}$ versus area (PA, TA) and closure (pre-post) were tested by full interaction two-way analysis of variance (ANOVA), followed by a posthoc test (Student's t-test on LS means).

\subsubsection{Species trophic characteristics}

To evaluate shifts in species trophic characteristics, we tested for differences of (a) trophic position (TP) and (b) energy flow (EF) after the cessation of trawling and (c) compared both parameters directly.

(a) Shifts in trophic position (TP). For 20 species (see Fig. 4) $\delta{ }^{15} \mathrm{~N}$ values were determined in specimens from both TA and PA 14 months after closure. Outliers in $\delta^{15} \mathrm{~N}$ were identified by Mahalanobis jackknife distances (Barnett and Lewis, 1994) and excluded from further analysis. $\delta^{15} \mathrm{~N}$ values were checked for normality (Kolmogorov-Smirnov test) and homogeneity of variances (Bartlett's test) and subsequently subjected to a full interaction two-way ANOVA of $\delta^{15} \mathrm{~N}$ versus area (PA, TA) and species, followed by a post-hoc test (Student's $t$-test on LS means). Variances were different at the $5 \%$ level albeit it did not increase with the mean, hence, we shifted our threshold level of significance from $p=0.05$ to $p=0.01$ (see Results). Trophic position difference $\Delta T P_{i}$ between PA and TA of species $i$ was calculated by

$$
\Delta T P_{i}=T P_{i, \mathrm{PA}}-T P_{i, \mathrm{TA}} \quad[\% \mathrm{o}]
$$

(b) Shifts in energy flow $(E F)$. Species energy flows were calculated for TA and PA prior to closure of the fishery and 1 year after closure (for number of samples see Trophic analyses of $E F_{\text {com }}$ ). Both indices, $E F_{i}$ and $R E F_{i}$ of the dominant species (comprising 99\% of $E F_{\text {com }}$ ) were tested for differences between TA and PA by Mann Whitney $U$-test $\left(R E F_{i}[\%]\right.$ values were arcsinetransformed). Species that showed significant differences of the same sign between TA and PA before and after closure, i.e. shifts apparently not caused by closure of the fishery, were excluded from further analysis.

(c) Correlation between changes in species TP and EF. In order to relate shifts in species energy flow to shifts in species trophic position $\left(\Delta T P_{i}\right)$, we plotted and correlated (Spearman's Rho, $p>0.05$ ) two different measures of difference in energy flow versus $\triangle T P_{i}$ :

(1) The magnitude of the shift in energy flow of species $i\left(\Delta E F_{i}\right)$ was described by the difference in energy flow between PA and $\mathrm{TA}$, expressed as fraction (\%) of the average energy flow in PA and TA

$$
\Delta E F_{i}=100 *\left(E F_{i, \mathrm{PA}}-E F_{i, \mathrm{TA}}\right) /\left(E F_{i, \mathrm{PA}}+E F_{i, \mathrm{TA}}\right) \quad[\%] .
$$

(2) The change in relative energy flow of species $i\left(\Delta R E F_{i}\right)$, i.e. of its share in community energy flow, was computed by the difference in $R E F_{i}$ between PA and TA

$$
\Delta R E F_{i}=100 *\left(E F_{i, \mathrm{PA}} / E F_{\text {com }, \mathrm{PA}}\right)-\left(E F_{i, \mathrm{TA}} / E F_{\text {com }, \mathrm{TA}}\right)
$$

\section{Results}

\subsection{Sediment}

Carbon content (C, \%) and silt-clay fraction $(<63 \mu \mathrm{m}, \%)$ did not significantly differ between sampling periods (pre-closure and postclosure), in either TA or PA. Median grain size $(\mu \mathrm{m})$ and organic carbon content $\left(\mathrm{C}_{\text {org }}\right.$, \%) differed significantly between sampling dates (preclosure and post-closure: $p<0.01$, Table 1 ). After 1 year of closure to fishery, the nitrogen content $(\mathrm{N}, \%)$ was significantly lower in the protected area $(p=0.02$, Table 1$)$.

\subsection{Community trophic characteristics}

Trophic position frequency distributions (TPFD) did not differ in median and varied slightly only in skewness and kurtosis, both between TA and PA and between sampling periods (pre-closure and post-closure, Fig. 3). TPFD did not significantly differ between sampling periods (pre-closure and post-closure) for both areas (TA and PA), whereas there were differences between TA and PA (Table 2). Thus, there was no detectable effect of the high trawling intensity during summers 2003 and 2004 (Fig. 2) or of trawling cessation (compare Fig. 3b with $3 d$ and Fig. $3 c$ with $3 d$, Table 2).

Neither pre-closure/post-closure $(p=0.30)$ nor area (PA-TA, $p=0.57)$ significantly affected community energy flow $\left(E F_{\text {com }}\right.$, see Fig. 3). However, the interaction pre-closure/post-closure $x$ area (PA-TA) was significant $(p<0.05)$, indicating an effect of trawling cessation on community energy flow. The post-hoc test identified TA 1 year after closure to be significantly different from the others $\left(\mathrm{TA}_{\text {pre }}=\mathrm{PA}_{\text {pre }}=\mathrm{PA}_{\text {post }}<\mathrm{TA}_{\text {post }} ; p<0.05\right)$.

\subsection{Species trophic position (TP)}

14 months after trawling closure, trophic positions $(T P)$ were significantly affected by species $(p<0.001)$ and by species $\times$ area (PA-TA) interaction $(p<0.001)$. Significant effects were detected in 4 species (Fig. 4). Within PA, TP was significantly $(p<0.01)$ higher in the deposit feeder Tellimya ferruginosa $\left(\Delta T P_{i}=1.18 \%\right.$ o), and significantly lower in the interface feeder, i.e. species that are able to switch between suspension and deposit feeding, Scolelepis bonnieri $(-2.14 \%$ ) as well as in the predators/scavengers E. pulchella $(-1.28 \%$ ) and Ophiura albida $(-1.03 \%$ ). A similar analysis (two-way ANOVA) on the level of major

Table 1

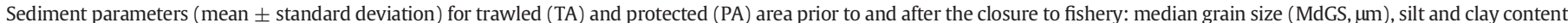

\begin{tabular}{|c|c|c|c|c|c|c|}
\hline Parameters & $\operatorname{MdGS}(\mu \mathrm{m})$ & $<63 \mu \mathrm{m}(\%)$ & C (\%) & $\mathrm{C}_{\text {org }}(\%)$ & $\mathrm{N}(\%)$ & $\mathrm{C} / \mathrm{N}$ \\
\hline \multicolumn{7}{|l|}{ Pre-closure } \\
\hline TA & $179 \pm 6$ & $4.73 \pm 1.45$ & $0.24 \pm 0.09$ & $0.08 \pm 0.03$ & n.d. & n.d. \\
\hline $\mathrm{PA}$ & $180 \pm 4$ & $3.85 \pm 1.04$ & $0.30 \pm 0.18$ & $0.08 \pm 0.02$ & n.d. & n.d. \\
\hline \multicolumn{7}{|l|}{ Post-closure } \\
\hline $\mathrm{TA}$ & $175 \pm 4$ & $4.08 \pm 1.32$ & $0.32 \pm 0.07$ & $0.15 \pm 0.02$ & $0.022 \pm 0.004$ & $7.04 \pm 1.11$ \\
\hline PA & $177 \pm 3$ & $3.34 \pm 0.92$ & $0.27 \pm 0.05$ & $0.13 \pm 0.02$ & $0.018 \pm 0.002$ & $6.97 \pm 0.74$ \\
\hline \multicolumn{7}{|l|}{ ANOVA results } \\
\hline Treatment (TA-PA) & 0.33 & 0.06 & 0.74 & 0.07 & 0.02 & 0.15 \\
\hline Closure (pre-post) & $<\mathbf{0 . 0 1}$ & 0.05 & 0.23 & $<\mathbf{0 . 0 1}$ & & \\
\hline
\end{tabular}

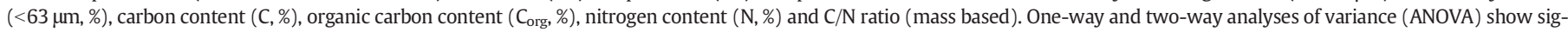
nificant differences $(p<0.05$, bold) between TA and PA, respectively pre-closure and post-closure. n.d.: no data. 
pre - closure
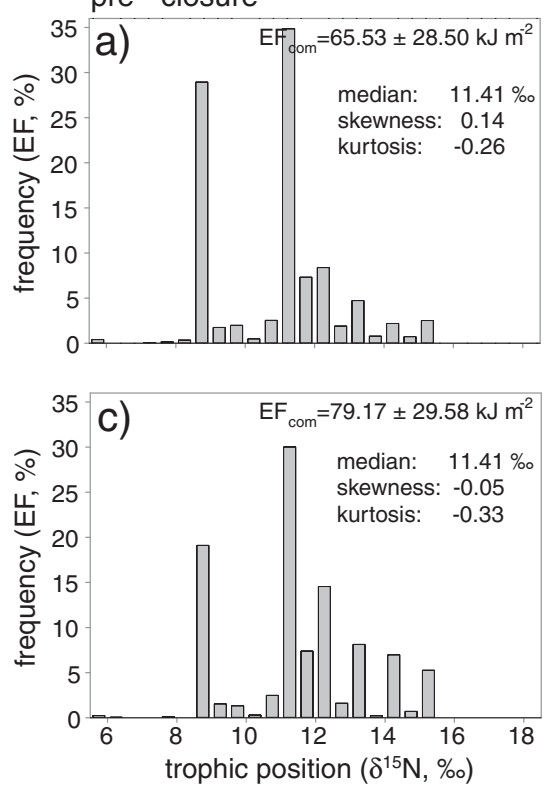

pre - closure
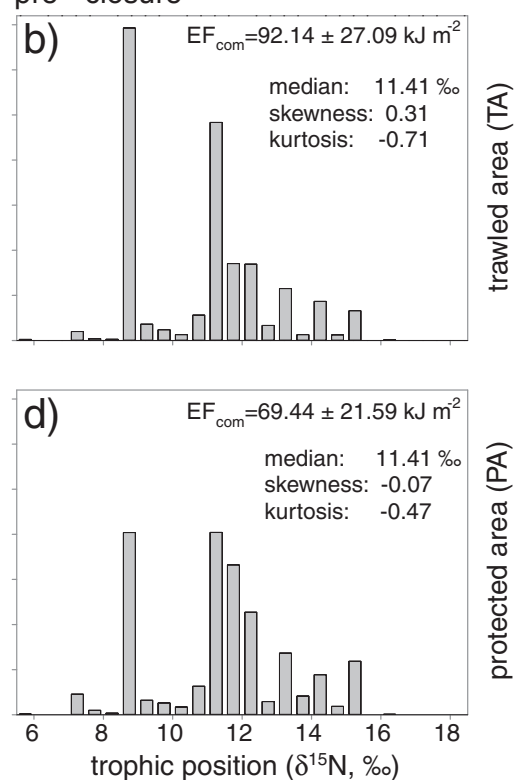

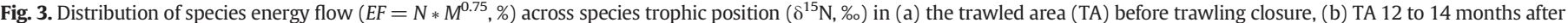

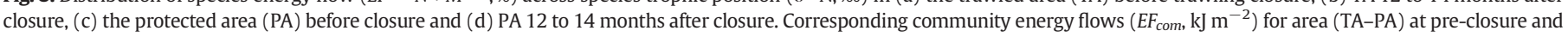
post-closure are given in the graphs.

feeding guilds (with DF, SF, SL, IF and PS, see classification of species in Fig. 4) detected no significant area effects (area $p=0.49$, feeding guilds $\times$ area $p=0.46$ ).

\subsection{Species energy flow (EF)}

Before closure, energy flow $E F_{i}$ differed significantly $(p<0.05)$ between PA and TA in 5 of those 70 species that represented $99 \%$ of community energy flow $\left(E F_{\text {com }}\right.$ ) (Fig. 5a). $E F_{i}$ was lower in PA in Tellina fabula and Magelona filiformis, and higher in P. serpens, Nephtys assimilis and $S$. bombyx. Corresponding significant differences in $R E F_{i}$ were present in $T$. fabula and $N$. assimilis only ( $p<0.05$, Fig. $5 b$ ).

One year after closure, $E F_{i}$ differed in 17 out of the 70 species $\left(p<0.05\right.$, Fig. 6a). In 7 species, $E F_{i}$ was lower in PA with $\triangle E F_{i}$ ranging from $-17.82 \mathrm{~kJ} \mathrm{~m}^{-2}$ (Echinocardium cordatum) to $-0.24 \mathrm{~kJ} \mathrm{~m}^{-2}$ ( $T$. ferruginosa). Ten species showed a higher $E F_{i}$ in PA, with differences in $\triangle E F_{i}$ ranging between $+0.06 \mathrm{~kJ} \mathrm{~m}^{-2}$ (Spio decoratus) and $+3.44 \mathrm{~kJ} \mathrm{~m}^{-2}$ (Owenia fusiformis). Note that $T$. fabula (lower in PA) and $S$. bombyx (higher in PA) showed the same pattern in $E F_{i}$ before closure (Fig. 5). Relative energy flow $R E F_{i}$ differed in 12 out of the 70 species (Fig. 6b). Only E. cordatum and T. ferruginosa had lower energy flow in PA with $\triangle R E F_{i}=-13.66 \%$ and $-0.23 \%$, respectively. $R E F_{i}$ was significantly higher in PA in the same 10 species mentioned previously (see $E F_{i}$ ), with $\triangle R E F_{i}$ ranging between $0.12 \%$ (S. decoratus) and $5.91 \%$ (O. fusiformis).

Table 2

P-values for pairwise tests (median rank test, rank sums) on significance differences of trophic position frequency distribution (TPFD) for trawled (TA) and protected area (PA) prior to (pre) and after (post) the closure to fishery. Significant differences $(p<0.05)$ are marked in bold.

\begin{tabular}{lllll}
\hline Parameters & TA pre & PA pre & TA post & PA post \\
\hline TA pre & - & - & - & - \\
PA pre & $\mathbf{0 . 0 1}$ & - & - & - \\
TA post & 0.65 & 0.05 & - & - \\
PA post & $<\mathbf{0 . 0 1}$ & 0.44 & $<\mathbf{0 . 0 1}$ & - \\
\hline
\end{tabular}

\subsection{Correlation between changes in species TP and EF}

$\Delta E F_{i}$ was negative in 17 but positive in 8 species only (Fig. 7a). Anthozoa $(+53 \%)$ and 0 . fusiformis $(+41 \%)$ showed the most pronounced increase, while the predators Corystes cassivelaunus and A. rubens showed the most pronounced decrease, $-100 \%$ and $-47 \%$, respectively. $\triangle R E F_{i}$ values were more evenly distributed, but comparatively small, ranging from $+6 \%$ (O. fusiformis and S. bombyx) to $-14 \%$ (E. cordatum, Fig. 7b). Those species with significant difference in trophic position $\triangle T P_{i}$ (S. bonnieri, E. pulchella, O. albida and T. ferruginosa) contributed comparatively little to community energy flow $\left(\Delta R E F_{i}<1 \%\right.$; Fig. 7b). Moreover, only one of these, $T$. ferruginosa, showed a significant difference in both $T P_{i}$ and $E F_{i}$ (or $R E F_{i}$, respectively) between TA and PA. No significant correlations were found between changes in trophic position $\Delta T P_{i}$ and changes in energy flow $\Delta E F_{i}(p=0.52)$, respectively changes in relative energy flow $\triangle R E F_{i}(p=0.67)$.

\section{Discussion}

Our results provide evidence that cessation of trawling leads to subtle changes in the trophic functioning of sandy bottom benthic communities, even over short time scales. At the community level, energy flow $(E F)$ differed between trawled (TA) and protected area (PA) after trawling cessation (see ANOVA-results, Section 3.2). In the trawled area, there was a shift in community energy flow $\left(E F_{\text {com }}\right)$ which was not detectable in PA. This indicates an effect of trawling on the temporal variability in $E F_{\text {com }}$ in TA which was suppressed in PA. As a consequence, $E F_{\text {com }}$ was lower in the protected area (PA), mainly caused by a lower $E F$ of $E$. cordatum. We were unable to detect shifts in community trophic structure. However, trophic changes could be detected at the level of species trophic characteristics: In PA, we found higher EF of interface feeders (e.g. O. fusiformis and S. bombyx) and, at the same time, a lower TP of deposit feeders (e.g. T. ferruginosa and Pectinaria koreni). The absence of physical sediment disturbance by fishing gear might be the principal cause of change (see further discussion). Further, TP and $E F$ of predators and scavengers was lower in PA compared to the further trawled area (TA) (e.g. O. albida, C. cassivelaunus, and A. rubens). This cessation induced trophic signal in the benthic community is, most 


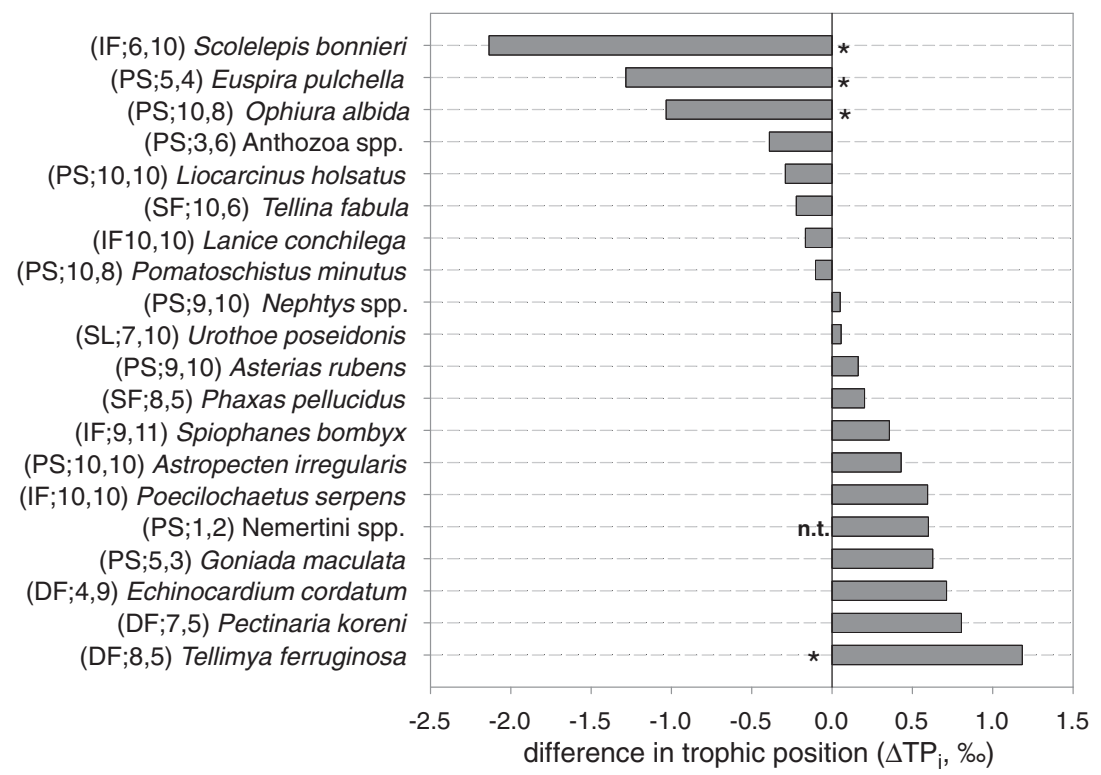

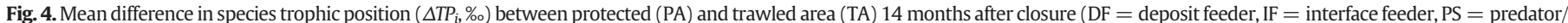

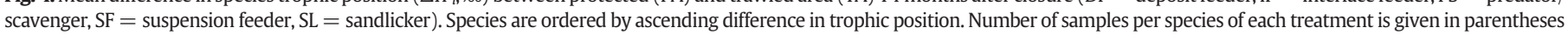
(trawled, protected). ${ }^{*}$ Significant difference $(p<0.01)$, n.t. means not tested.

likely, linked to the missing food sources (bycatch, discards) that are usually generated by trawling. In the following, the causal relations between the observed changes and trawling cessation are discussed.

Trawling cessation affected the sedimentary biochemistry and structure of the study site significantly. Nitrogen and organic carbon content, as well as the fine sediment fraction (silt and clay) were lower in PA compared to TA (Table 1). Concentrations of organic compounds at the sediment surface are reduced by the interaction of biological processing and trawling cessation. Frequent trawling enhances the availability of otherwise buried organic compounds (e.g. Trimmer et al., 2005; Watling et al., 2001) and thus affects sediment physics (e.g. resuspension) and biogeochemistry. Accordingly, trawling cessation led to a lowered community energy flow $\left(E F_{c o m}\right)$ in PA, too, particularly owing to lower $E F$ of the infaunal deposit feeder $E$. cordatum. The species prefers sediments enriched in organic matter (Kröncke et al., 2004; Wieking and Kröncke, 2003) and populations of the species appear to be rather less affected than other large animals by beam trawling (Kaiser et al., 2006; Tillin et al., 2006), particularly larger specimens which burrow deep in the sediment (e.g. Bergman and Hup, 1992).

In contrast, small interface feeders with a more or less sessile lifestyle (O. fusiformis, S. bombyx, Chaetozone cf. setosa, Edwardsia spp. and $S$. decoratus) had a higher EF in PA. These species feed selectively on
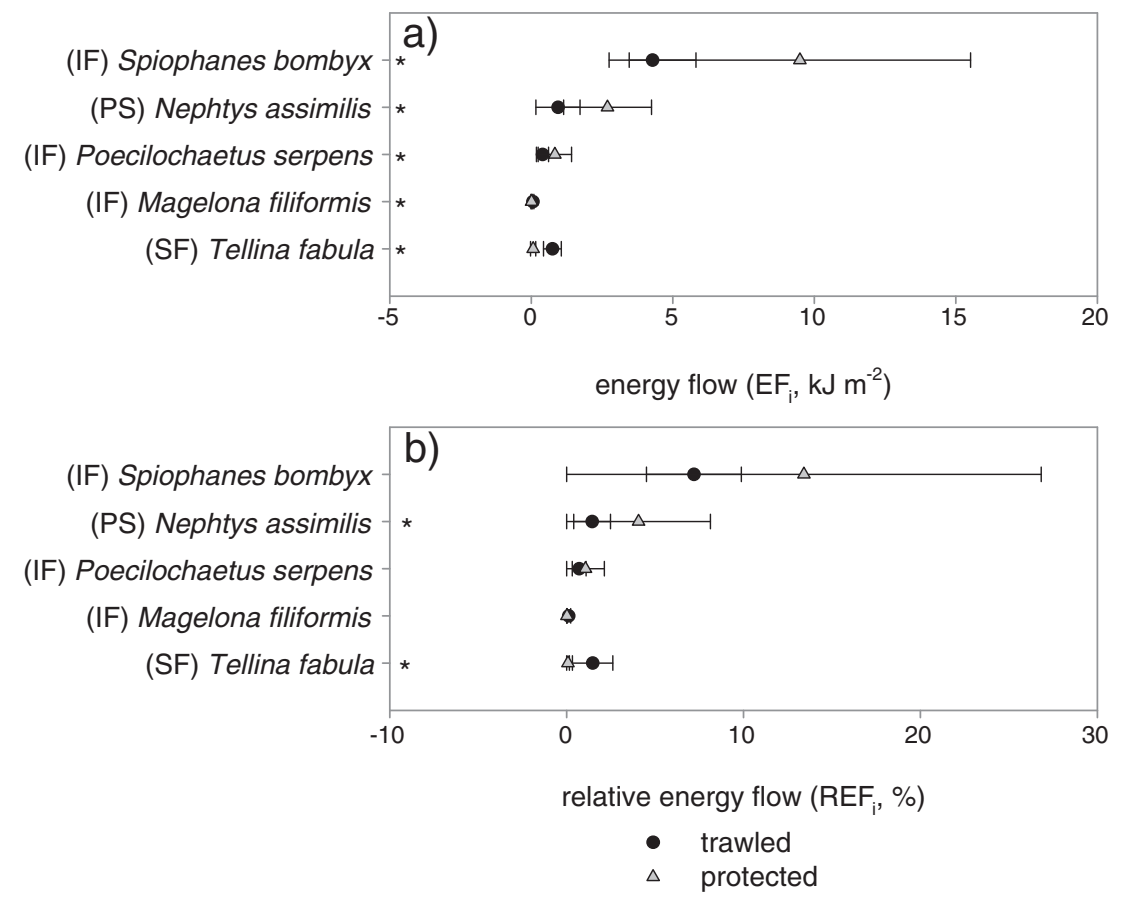

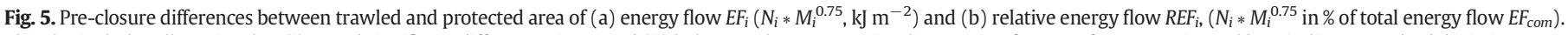

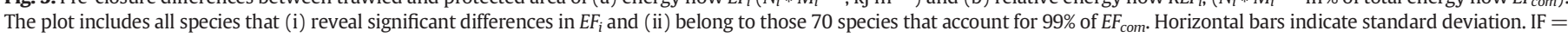
interface feeder, $\mathrm{PS}=$ predator/scavenger, $\mathrm{SF}=$ suspension feeder. Species were ordered by increasing difference in energy flow $(\mathrm{PA}$ minus TA). *Significant difference $(p<0.05)$. 

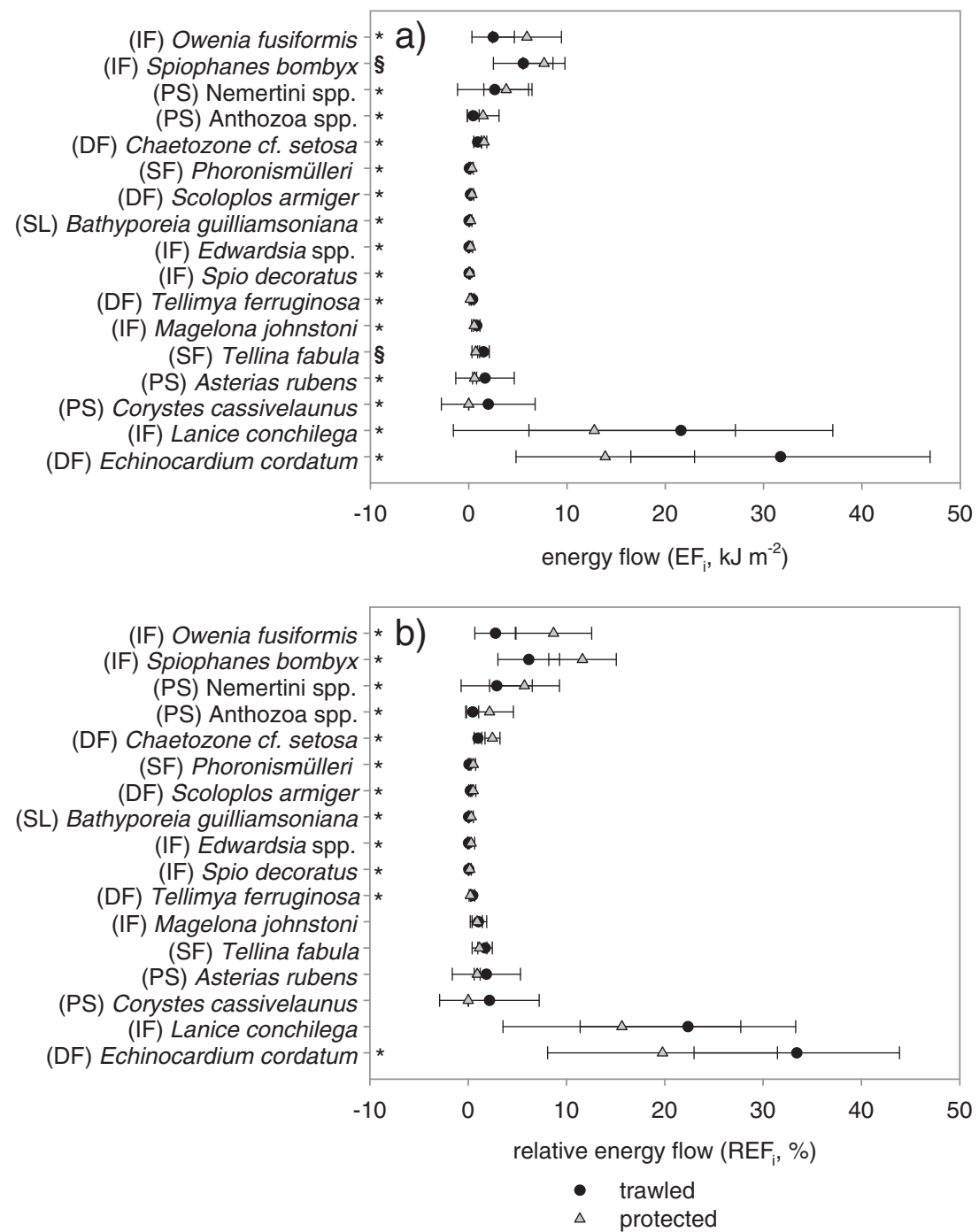

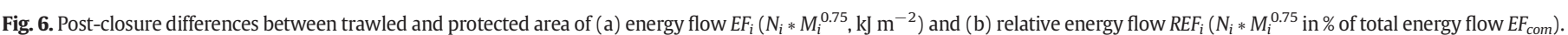

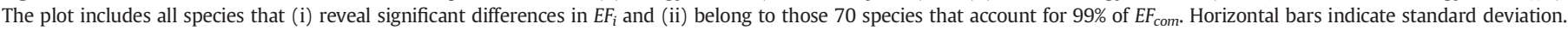

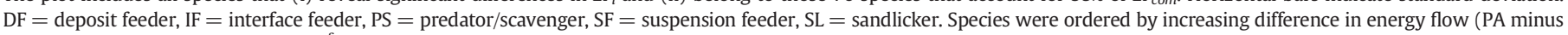
TA). *Significant difference $(p<0.05)$, ${ }^{\S}$ significant difference of the same sign before and after closure $(p<0.05)$.

high quality (indicated by low C/N ratio, Brown et al., 2005) food particles (e.g. Kröncke et al., 2004; Wieking and Kröncke, 2005). Sediment $\mathrm{C} / \mathrm{N}$ ratios, however, did not differ between TA and PA. Therefore, the absence of physical disturbance rather than enhanced food quality is responsible for their stronger presence in PA (see also Collie et al., 2005; De Juan et al., 2007). Stronger presence of small interface feeders might have led to an increased processing of sedimentary organic compounds (as evident in lower nitrogen and carbon content), i.e. a biological feedback process as also observed by Brown et al. (2005).

TPs of deposit feeders such as P. koreni and E. cordatum, as well as its commensal $T$. ferruginosa which feeds on refractory material of E. cordatum (Gage, 1966), were increased. This may be related to an altered sediment biogeochemistry in PA, too: Microbial activity and degradation not only alters the general composition of sediment POM (e.g. Lee et al., 2004), but also increases $\delta^{15} \mathrm{~N}$ of bulk POM by the release of ${ }^{15} \mathrm{~N}$ depleted nitrogen compounds (e.g. Macko and Estep, 1984; Wada, 1980). Trawling causes a decrease in benthic microbial activity (Pusceddu et al., 2005) and, most likely, a corresponding decrease in POM $\delta^{15} \mathrm{~N}$. Hence, if POM in PA has a higher $\delta^{15} \mathrm{~N}$, this signal will be passed on to the benthic primary consumers, in particular to deposit feeders feeding on refractory material. We were unable to demonstrate changes in POM $\delta^{15} \mathrm{~N}$, but obviously trawling affected the sedimentary biochemistry significantly (nitrogen and organic carbon, see Table 1).

The second cause for a cessation induced trophic signal in the benthic community is the absence of fishery generated additional and artificial food sources, i.e. gear-induced mortality and discards. Primarily, trawling causes mortality of benthic organisms, but many survivors, especially mobile predators and scavengers profit from this additional source of comparatively high trophic level food (Arntz and Weber, 1970; Groenewold and Fonds, 2000; Rumohr and Kujawski, 2000). After short-term closure, we thus expected the see first alterations of $E F$ and $T P$ of these mobile species that benefit from fishery bycatch and discards. According to the lack of these additional food sources, we expected TP of predators and scavengers to be lower in PA. Such shifts in TP were observed in the apparently facultative predating/ scavenging $O$. albida, E. pulchella and the usually interface feeding species S. bonnieri (see Kenchington et al., 1998; Nagabhushanam and Colman, 1959). Surprisingly, we were unable to prove changes in TP in those large, mobile predators and scavengers which are known to benefit from such additional food sources, such as Liocarcinus spp., A. rubens and A. irregularis (Figs. 4 and 7). Obviously, these large, opportunistic feeders cover such a trophically wide prey range (e.g. Cohen et al., 

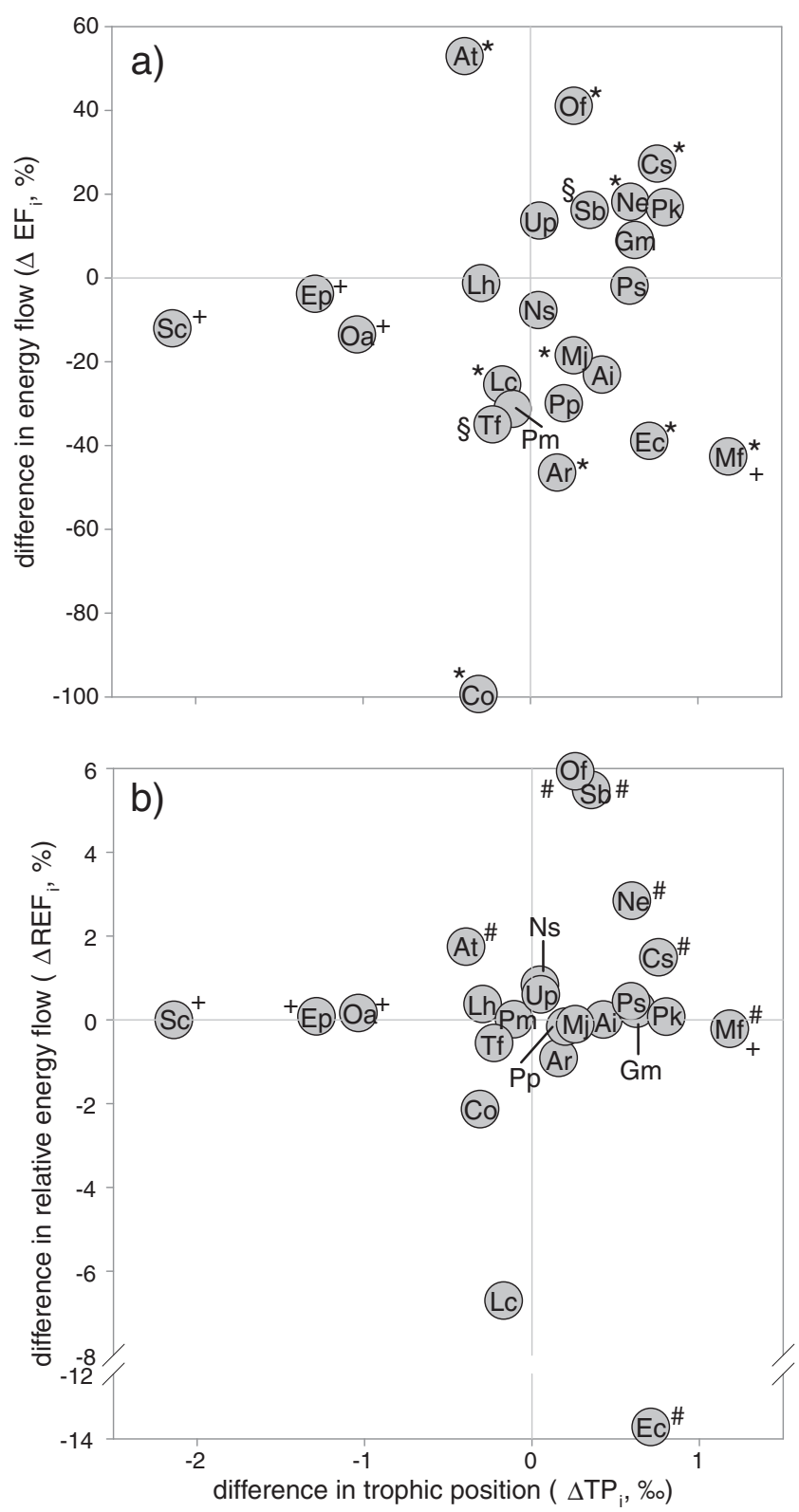

Fig. 7. Differences in species trophic position $\left(\triangle T P_{i}, \%\right.$ ) versus (a) difference in species energy flow $\left(\triangle E F_{i}\right)$ as \% of species value in the whole study area and (b) difference in relative energy flow $\left(\triangle R E F_{i}\right)$ as change in the $\%$ share of the species in total energy flow. Species are At: Anthozoa spp., Ar: Asterias rubens, Ai: Astropecten irregularis, Cs: Chaetozone cf. setosa, Co: Corystes cassivelaunus, Ec: Echinocardium cordatum, Ep: Euspira pulchella, Gm: Goniada maculata, Lc: Lanice conchilega, Lh: Liocarcinus holsatus, Mj: Magelona johnstoni, Ne: Nemertini spp., Ns: Nephtys spp., Oa: Ophiura albida, Of: Owenia fusiformis, Pk: Pectinaria koreni, Pp: Phaxas pellucidus, Ps: Poecilochaetus serpens, Pm: Pomatoschistus minutus, Sc: Scolelepis bonnieri, Sb: Spiophanes bombyx, Mf: Tellimya ferruginosa, Tf: Tellina fabula, Up: Urothoe poseidonis. For species $\mathrm{Cs}, \mathrm{Co}, \mathrm{Mj}$ and $\mathrm{Of}$, mean $\Delta T P_{i}$, of the corresponding feeding guild was used. ${ }^{*}$ Significant difference in $T P_{i}(p<0.01),{ }^{+}$significant difference in $E F_{i}$ $(p<0.05)$, "\# significant difference in $R E F_{i}(p<0.05)$, ${ }^{\S}$ significant difference of the same sign before and after closure $(p<0.05)$.

1993; Davenport and Bax, 2002; Pimm and Lawton, 1978) that a fishery related shift in diet is not detectable in species TP at the scale of our study. There is, however, a clear signal in $E F$ which is distinctly lower in PA in predators and scavengers such as $C$. cassivelaunus and A. rubens (Fig. 7). Scarcity of those food items commonly generated by trawling may have triggered them to emigrate from PA (see De Juan et al., 2007; Groenewold and Fonds, 2000; Smith et al., 2006).
At the community level, however, we were not able to detect changes in the distribution of TP among species as were Jennings et al. (2001a), although we expected on average lower TPs in PA due to lower $E F$ of predators and scavengers. This is a general problem of cause and effect studies targeting trawling impact in areas such as the North Sea. Coastal habitats with pronounced environmental dynamics combined with numerous and continuous anthropogenic impacts make such studies extremely difficult (e.g. Collie et al., 2000; Gray et al., 2006). Accordingly, estimates of recovery time for North Sea benthos are based on experimental trawling or on the comparison of "lightly" and "heavily" trawled areas (Collie et al., 2000; Kaiser et al., 2006). Models derived from these estimates predict recovery rates of 100 days in terms of numerical abundance (Collie et al., 2000) and 1-3 years in terms of biomass and production (Hiddink et al., 2006b) from beam trawling for sandy bottom communities. Soft-bottom monitoring studies, however, indicate longer recovery times after perturbations, in terms of biomass more than 3 years (see e.g. Pearson and Rosenberg, 1978; Arntz and Rumohr, 1982). Smith et al. (2006) found lowered epifaunal biomass even 3 years after closure of the fishery in a southern North Sea area. Collie et al. (2005) report an increase in benthic abundance, biomass and production after 2.5 years on gravel bottoms (Georges Bank) that continued until 5 years after closure (end of observational period). Only two studies so far dealt with infaunal recovery. De Juan et al. (2007) found fewer scavengers but increased surface infauna and more epifauna, in particular suspension feeders and predatory fish 1 year after closure of a muddy habitat situated in the north-western Mediterranean Sea. Duineveld et al. (2007) report an increase in species richness, evenness, and abundance of mud shrimps and fragile large bivalves in epifaunal beam-trawl samples, but inconsistent results in infaunal box-core samples of a sandy habitat (southern North Sea), even after 20 years of closure. Further comparable data for shallow sandy bottoms are lacking or difficult to interpret owing to the systems' natural dynamics (e.g. Collie et al., 2000; Kaiser et al., 2006).

Our study may have been hampered by some of these problems in coastal dynamic systems as well, which might have prevented us from detecting significant trophic alterations. We are aware that measuring all species TPS over the course of the whole sampling period would have been more reliable to detect potential food-input changes by trawling. However, all other measured parameters $\left(E F, E F_{\text {com }}\right)$ showed the same temporal pattern without differences between PA and TA before fishery cessation but with differences between the areas after PA had been closed for fishery. Given the consistency of this pattern over all other parameters measured, we are convinced that the observed differences in TP among the two areas reflect the outcome of differential developments due to trawling cessation and not natural spatial variation. Regarding community trophic properties only, data from one or two sampling dates combined with site-calibrated literature data provide sufficient accuracy to look for trophic changes of communities sampled in field surveys in a pragmatic way. Particularly, EF seems to be a promising indicator of energy flow changes in the benthos. However, to detect species specific changes of TP direct measurements of $\delta^{15} \mathrm{~N}$ are required (see Figs. 4 and 7), as particularly low TP species are susceptible to seasonal and spatial variability in stable isotope ratios (Lorrain et al., 2002). Further, compared to at least 5 decades of intense trawling (e.g. Lindeboom and de Groot, 1998; Rumohr and Kujawski, 2000), our 14-month study of post-trawling changes in the benthos is short-term, and compared to a sea of disturbance a protected area of $500 \mathrm{~m}$ in radius (PA) is rather small. It is likely that organisms migrated in and/or out of the protected area (see e.g. De Juan et al., 2007). Migrating organisms can also be part of the recovery process (e.g. Arntz and Rumohr, 1982), but might have contaminated or diluted species trophic signals. Obviously, trophic characteristics changed in PA despite its small size and previous studies on trawling cessation indicated functional shifts in small sized areas as well (De Juan et al., 2007, 2011; Duineveld et al., 2007). Nevertheless, recovery might be limited or decelerated by the adjacent fished areas (see also De Juan et al., 2011). 
Thus trophic changes at the community level may have remained low during the first 14 months so that only distinct species trophic alteration may have been measurable. This would argue towards (a) a larger size of no-take zones in the future to exclude the effects of fishing grounds in the surrounding and (b) a detection of trophic shifts at the species level in particular. For example, Tillin et al. (2006) were unable to demonstrate consistent changes in functional diversity at the Dogger Bank (North Sea), although they provided evidence that continuous bottom trawling affects community functional composition. Our results support the findings of functional changes in the benthic community (De Juan et al., 2007; Tillin et al., 2006). However, TP changes ( $\Delta T P$ ) at the level of major feeding guilds were not significant (see previous discussion) and the detected changes in trophic properties were most pronounced at the species level. This emphasises that species sensitivity to disturbances seems to be the best indicator for short-term trophic changes because every response of a system starts with the response of certain species. The species is thus the smallest entity to alter communities' ecological functioning. Hence, classification of organisms into groups or guilds might hamper cause and effect studies in highly dynamic coastal areas. This underlines the statement of Pearson (2007): 'Do not classify! Look how organisms create, maintain and change their habitat!' Shifts in species trophic position, however, are rather small compared to trawling effects in hitherto pristine systems. Those species with a significant $\triangle T P$ contributed comparatively little to $E F_{\text {com }}$ and vice versa (Fig. 7). Apparently, no single species pushes the system towards one direction and explains why community trophic structure is still similar in TA and PA after 14 months of trawling cessation. Possibly, long-term bottom trawling has created a high degree of trophic generalism (Berlow, 1999; McCann et al., 1998) and functional redundancy among the benthic species (Jennings et al., 2001a; Menge and Sutherland, 1987; Yachi and Loreau, 1999) hampered rapid recovery of the trophic system after trawling cessation. Long-term studies are required to provide evidence that trophic properties cause resistance against anthropogenic stressors in North Sea soft-bottom communities.

The forthcoming offshore wind farms in the German Bight present a unique scientific opportunity to study effects of long-term and largescale cessation of trawling on the benthos, as active trawling will be prohibited in the wind farm areas. It remains to be seen whether trawling cessation will cause a benthic regime shift (sensu Amaro, 2005; Allen and Clarke, 2007; Van Nes et al., 2007) towards a high biomass-low turnover system, presumably with higher biodiversity (see Worm et al., 2006). Long-term, trawling cessation may support an increase in habitat complexity, i.e. an opposed development of decades of trawling (Callaway et al., 2007; Riesen and Reise, 1982). This gain in refuges may have a significant influence on growth and survivorship of species and thus on species and trophic diversity in the benthic system (Briand and Cohen, 1987; Thrush and Dayton, 2002). Whether the observed short-term trophic changes we found will become permanent in the long run remain to be seen. Offshore wind farms will provide the possibility to investigate species inventory and food web structure and the time-scale of recovery processes in the absence of trawling.

\section{Acknowledgements}

We thank S. Ehrich (Federal Research Centre for Fisheries, Hamburg) for the supplied German VMS data, G. Piet and F. Quirins (Netherlands Institute for Fisheries Research) for the Dutch ones. We thank M. Bergmann and E. Gentsch for providing one nitrogen isotope ratio each. We thank M. Klein for her help in preparing stable isotope samples and U. Struck for mass spectrometric analyses. We thank B. Ebbe, L. Gutow, H. Reiss, S. Thrush and one anonymous reviewer for helpful comments on an earlier version of this manuscript. The crew of the "RV Heincke" supported us substantially during all cruises. This study was funded by the European Union RESPONSE project (QLRT-200100787).

\section{Appendix 1. Supplementary data}

Supplementary data to this article can be found online at http://dx. doi.org/10.1016/j.seares.2013.09.005.

\section{References}

Allen, J.I., Clarke, K.R., 2007. Effects of demersal trawling on ecosystem functioning in the North Sea: a modelling study. Mar. Ecol. Prog. Ser. 336, 63-75.

Amaro, T.P.F. 2005. The Benthic Shift of the Frisian Front (Southern North Sea) Ecosystem - Possible Mechanisms. (PhD thesis) Wageningen University, Wageningen.

Arntz, W.E., Rumohr, H., 1982. An experimental study of macrobenthic colonization and succession, and the importance of seasonal variation in temperate latitudes. J. Exp. Mar. Biol. Ecol. 64, 17-46.

Arntz, W.E., Weber, W., 1970. Cyprina islandica L. (Mollusca, Bivalvia) als Nahrung von Dorsch und Kliesche in der Kieler Bucht. Ber. Dtsch. Wiss. Komm. Meeresforsch. 21, 193-209.

Badalamenti, F., D'Anna, G., Pinnegar, J.K., Polunin, N.V.C., 2002. Size-related trophodynamic changes in three target fish species recovering from intensive trawling. Mar. Biol. 141, 561-570.

Barnett, V., Lewis, T., 1994. Outliers in Statistical Data. Wiley, New York.

Bergman, M.J.N., Hup, M., 1992. Direct effects of beamtrawling on macrofauna in a sandy sediment in the southern North Sea. ICES J. Mar. Sci. 49, 5-11.

Bergman, M.J.N., van Santbrink, J.W., 2000. Mortality in megafaunal benthic populations caused by trawl fisheries on the Dutch continental shelf in the North Sea in 1994. ICES J. Mar. Sci. 57, 1321-1331.

Berlow, E.L., 1999. Strong effects of weak interactions in ecological communities. Nature 398, 330-334.

Blanchard, F., LeLoc'h, F., Hily, C., Boucher, J., 2004. Fishing effects on diversity, size and community structure of the benthic invertebrate and fish megafauna on the Bay of Biscay coast of France. Mar. Ecol. Prog. Ser. 280, 249-260.

Brey, T., 2001. Population Dynamics in Benthic Invertebrates. A Virtual Handbook. (Version 01.2. http://www.thomas-brey/science/handbook).

Briand, F., Cohen, J., 1987. Environmental correlates of food chain length. Science 238, 956-960.

Brown, E.J., Finney, B., Dommisse, M., Hills, S., 2005. Effects of commercial otter trawling on the physical environment of the southeastern Bering Sea. Cont. Shelf Res. 25, $1281-1301$

Callaway, R., Engelhard, G.H., Dann, J., Cotter, J., Rumohr, H., 2007. A century of North Sea epibenthos and trawling: comparison between 1902-12, 1982-85 and 2000. Mar. Ecol. Prog. Ser. 346, 27-43.

Clark, R.A., Frid, C.L.J., 2001. Long-term changes in the North Sea ecosystem. Environ. Rev. 9, 131-187.

Cohen, J.E., 1978. Food Webs and Niche Space. Princeton University Press, Princeton, New Jersey.

Cohen, J.E., Pimm, S.L., Yodzis, P., Saldana, J., 1993. Body sizes of animal predators and animal prey in food webs. J. Anim. Ecol. 62, 67-78.

Cohen, J.E., Jonsson, T., Carpenter, S.R., 2003. Ecological community description using the food web, species abundance, and body size. Proc. Natl. Acad. Sci. U. S. A. 100, $1781-1786$

Collie, J.S., Hall, S.J., Kaiser, M.J., Poiner, I.R., 2000. A qualitative analysis of fishing impacts on shelf-sea benthos. J. Anim. Ecol. 69, 785-798.

Collie, J.S., Hermsen, J.M., Valentine, P.C., Almeida, F.P., 2005. Effects of fishing on gravel habitats: assessment and recovery of benthic megafauna on Georges Bank. American Fisheries Society Symposium, 41, pp. 325-343.

Cranfield, J.H. Michael, K.P. Doonan, IJ. 1999. Changes in the distribution of epifaunal reefs and oysters during 130 years of dredging for oysters in Foveaux Strait, southern New Zealand. Aquat. Conserv.: Mar. Freshwater Ecosyst. 9, 461-483.

Dannheim, J., 2007. Macrozoobenthic Response to Fishery - Trophic Interactions in Highly Dynamic Coastal Ecosystems. Dissertation University of Bremen, Bremen (http://nbn-resolving.de/urn:nbn:de:gbv:46-diss000108658).

Davenport, S.R., Bax, N.J., 2002. A trophic study of a marine ecosystem off southeastern Australia using stable isotopes of carbon and nitrogen. Can. J. Fish. Aquat. Sci. 59, 514-530.

Dayton, P.K., Thrush, S.F., Agardy, M.T., Hofman, R.J., 1995. Environmental effects of marine fishing. Aquat. Conserv.: Mar. Freshwater Ecosyst. 5, 205-232.

De Juan, S., Thrush, S.F., Demestre, M., 2007. Functional changes as indicators of trawling disturbance on a benthic community located in a fishing ground (NW Mediterranean Sea). Mar. Ecol. Prog. Ser. 334, 117-129.

De Juan, S. Demestre, M., Sanchez, P., 2011. Exploring the degree of trawling disturbance by the analysis of benthic communities ranging from a heavily exploited fishing ground to an undisturbed area in the NW Mediterranean. Sci. Mar. 75, 507-516.

Duineveld, G.C.A., Bergman, M.J.N., Lavaleye, M.S.S., 2007. Effects of an area closed to fisheries on the composition of the benthic fauna in the southern North Sea. ICES J. Mar. Sci. 64, 899-908.

Dunne, J.A., Williams, R.J., Martinez, N.D., 2002. Network structure and biodiversity loss in food webs: robustness increases with connectance. Ecol. Lett. 5, 558-567.

Gage, J.D., 1966. Observations on the bivalves Montacuta substriata and M. ferruginosa, 'commensals' with spatangoids. J. Mar. Biol. Assoc. U. K. 46, 49-70.

Gray, J.S., Dayton, P., Thrush, S., Kaiser, M.J., 2006. On effects of trawling, benthos and sampling design. Mar. Pollut. Bull. 52, 840-843.

Groenewold, S., Fonds, M., 2000. Effects on benthic scavengers of discards and damaged benthos produced by the beam-trawl fishery in the southern North Sea. ICES J. Mar. Sci. 57, 1395-1406. 
Hiddink, J.G., Jennings, S., Kaiser, M.J., Queirós, A.M., Duplisea, D.E., Piet, G.J., 2006a Cumulative impacts of seabed trawl disturbance on benthic biomass, production, and species richness in different habitats. Can. J. Fish. Aquat. Sci. 63, 721-736.

Hiddink, J.G., Jennings, S., Kaiser, M.J., 2006b. Indicators of the ecological impact of bottom-trawl disturbance on seabed communities. Ecosystems 9, 1190-1199.

Jacob, U., Mintenbeck, K., Brey, T., Knust, R., Beyer, K., 2005. Stable isotope food web studies: a case for standardized sample treatment. Mar. Ecol. Prog. Ser. 287, 251-253.

Jennings, S., Kaiser, M.J., 1998. The effects of fishing on marine ecosystems. Adv. Mar. Biol. 34, 201-352.

Jennings, S., Pinnegar, J.K., Polunin, N.V.C., Warr, K.J., 2001a. Impacts of trawling disturbance on the trophic structure of benthic invertebrate communities. Mar. Ecol. Prog. Ser. 213, 127-142.

Jennings, S., Dinmore, T.A., Duplisea, D.E., Warr, K.J., Lancaster, J.E., 2001b. Trawling disturbance can modify benthic production processes. J. Anim. Ecol. 70, 459-475.

Jennings, S., Pinnegar, J.K., Polunin, N.V.C., Warr, K.J., 2002a. Linking size-based and trophic analyses of benthic community structure. Mar. Ecol. Prog. Ser. 226, 77-85.

Jennings, S., Greenstreet, S.P.R., Hill, L., Piet, G.J., Pinnegar, J.K., Warr, K.J., 2002b. Long-term trends in the trophic structure of the North Sea fish community: evidence from stableisotope analysis, size-spectra and community metrics. Mar. Biol. 141, 1085-1097.

Joschko, T.J., 2007. Influence of Artificial Hard Substrates on Recruitment Success of the Zoobenthos in the German Bight, Dissertation. Carl von Ossietzky University, Oldenburg.

Kaiser, M.J., Collie, J.S., Hall, S.J., Jennings, S., Poiner, I.R., 2002. Modification of marine habitats by trawling activities: prognosis and solutions. Fish Fish. 3, 114-136.

Kaiser, M.J., Clarke, K.R., Hinz, H., Austen, M.C.V., Somerfield, P.J., Karakassis, I., 2006. Global analysis of response and recovery of benthic biota to fishing. Mar. Ecol. Prog. Ser. 311, 1-14

Kenchington, E., Duggan, R., Riddell, T., 1998. Early life history characteristics of the razor clam (Ensis directus) and the moonsnails (Euspira spp.) with applications to fisheries and aquaculture. Canadian Technical Report of Fisheries and Aquatic Sciences, p. 2223.

Kröncke, I., Zeiss, B., Rensing, C., 2001. Long-term variability in macrofauna species composition off the Island of Norderney (East Frisia, Germany) in relation to changes in climatic and environmental conditions. Senckenb. Marit. 31, 65-82.

Kröncke, I., Stoeck, T., Wieking, G., Palojärvi, A., 2004. Relationship between structural and functional aspects of microbial and macrofaunal communities in different areas of the North Sea. Mar. Ecol. Prog. Ser. 282, 13-31.

Lee, C., Wakeham, S., Arnosti, C., 2004. Particulate organic matter in the sea: the composition conundrum. Ambio 33, 565-575.

Lindeboom, H.J., de Groot, S.J., 1998. IMPACT II: The Effects of Different Types of Fisheries on the North Sea and Irish Sea Benthic Ecosystem. NIOZ-rapport 1998-1, RIVO-DLO report CO03/98.Netherlands Institute for Sea Research, Den Burg, Texel.

Lorrain, A., Paulet, Y.M., Chauvaud, L., Savoye, N., Donval, A., Saout, C.H., 2002. Differential $\delta^{13} \mathrm{C}$ and $\delta^{15} \mathrm{~N}$ signatures among scallop tissues: implications for ecology and physiology. J. Exp. Mar. Biol. Ecol. 275, 47-61.

Macko, S.A., Estep, M.L.F., 1984. Microbial alteration of stable nitrogen and carbon isotopic compositions of organic matter. Org. Geochem. 6, 787-790.

Malakoff, D., 2002. Sea-floor ecosystems: trawling's a drag for marine life, say studies. Science 298, 2123.

Mateo, M.A., Serrano, O., Serrano, L., Michener, R.H., 2008. Effects of sample preparation on stable isotope ratios of carbon and nitrogen in marine invertebrates: implications for food web studies using stable isotopes. Oecologia 157, 105-115.

May, R.M., 1974. Stability and Complexity in Model Ecosystems. Princeton University Press, Princeton, New Jersey.

McCann, K., Hastings, A., Huxel, G.R., 1998. Weak trophic interactions and the balance in nature. Nature 395, 794-798.

McCutchan, J.H., Lewis Jr., W.M., Kendall, C., McGrath, C.C., 2003. Variation in trophic shift for stable isotope ratios of carbon, nitrogen and sulfur. Oikos 102, 378-390.

Menge, B.A., Sutherland, J.P., 1987. Community regulation: variation in disturbance, competition, and predation in relation to environmental stress and recruitment. Am. Nat. 130, 730-757.

Nagabhushanam, A.K., Colman, J.S., 1959. Carrion-eating by ophiuroids. Nature 184, 285.

Pastoors, M.A., Rijnsdorp, A.D., van Beek, F.A., 2000. Effects of a partially closed area in the North Sea ("plaice box") on stock development of plaice. ICES J. Mar. Sci. 57, 1014-1022.

Pearson, T.H., 2007. Biodiversity effects on ecosystem functioning. Keynote Lecture, 42nd European Marine Biology Symposium, 27-31 August, Kiel, Germany.

Pearson, T.H., Rosenberg, R., 1978. Macrobenthic succession in relation to organic enrichment and pollution of the marine environment. Oceanogr. Mar. Biol. Annu. Rev. 16, 229-311.

Peterson, P.B., Fry, B., 1987. Stable isotopes in ecosystem studies. Annu. Rev. Ecol. Syst. 18, 293-320.

Piet, G.J., Rijnsdorp, A.D., 1998. Changes in the demersal fish assemblage in the southeastern North Sea following the establishment of a protected area ('plaice box'). ICES J. Mar. Sci. 55, 420-429.

Pimm, S.L., 1982. Food Webs. Chapman and Hall, London.
Pimm, S.L., Lawton, J.H., 1978. On feeding on more than one trophic level. Nature 275 542-544.

Post, D.M., 2002. Using stable isotopes to estimate trophic position: models, methods, and assumptions. Ecology 83, 703-718.

Pusceddu, A., Fiordelmondo, C., Danovaro, R., 2005. Sediment resuspension effects on the benthic microbial loop in experimental microcosms. Microb. Ecol. 50, 602-613.

Queirós, A.M., Hiddink, J.G., Kaiser, M.J., Hinz, H., 2006. Effects of chronic trawling disturbance on benthic biomass, production and size spectra in different habitats. J. Exp. Mar. Biol. Ecol. 335, 91-103.

Ramsay, K., Kaiser, M.J., Richardson, C.A., Veale, L.O., Brand, A.R., 2000. Can shell scars on dog cockles (Glycymeris glycymeris L.) be used as an indicator of fishing disturbance? J. Sea Res. 43, 167-176.

Reise, K., 2005. Coast of change: habitat loss and transformations in the Wadden Sea. Helgol. Mar. Res. 59, 9-21.

Riesen, W., Reise, K., 1982. Macrobenthos of the subtidal Wadden Sea: revisited after 55 years. Helgol. Mar. Res. 35, 409-423.

Rijnsdorp, A.D., Buys, A.M., Storbeck, F., Visser, E.G., 1998. Micro-scale distribution of beam trawl effort in the southern North Sea between 1993 and 1996 in relation to the trawling frequency of the sea bed and the impact on benthic organisms. ICES J. Mar. Sci. 55, 403-419.

Rumohr, H., Kujawski, T., 2000. The impact of trawl fishery on the epifauna of the southern North Sea. ICES J. Mar. Sci. 57, 1389-1394.

Schröder, A., Dannheim, J., 2006. Estimation of fishing effort in the ASA of the North Sea. In: Demestre, M. (Ed.), Response of Benthic Communities and Sediment to Different Regimens of Fishing Disturbance in European Coastal Waters (RESPONSE). Final Report of the EU project Q5RS-2002-00787. ICM-CSIC, Barcelona, pp. 107-129.

Schröder, A., Gutow, L., Joschko, T., Krone, R., Gusky, M., Paster, M., Potthoff, M., 2008 Benthosökologische Auswirkungen von Offshore-Windenergieparks in der Nordsee (BeoFINO II) (Benthic ecological implications of offshore wind farms in the North Sea (BeoFINO II)). Final Project Report of the BMU Project 0329974A.

Smith, R., Boyd, S.E., Rees, H.L., Dearnaley, M.P., Stevenson, J.R., 2006. Effects of dredging activity on epifaunal communities - surveys following cessation of dredging. Estuar. Coast. Shelf Sci. 70, 207-223.

Thrush, S.F., Dayton, P.K., 2002. Disturbance to marine benthic habitats by trawling and dredging: implications for marine biodiversity. Annu. Rev. Ecol. Syst. 33, 449-473.

Thrush, S.F., Hewitt, J.E., Funnell, G.A., Cummings, V.J., Ellis, J., Schultz, D., Talley, D. Norkko, A., 2001. Fishing disturbance and marine biodiversity: role of habitat structure in simple soft-sediment systems. Mar. Ecol. Prog. Ser. 221, 255-264.

Tillin, H.M., Hiddink, J.G., Jennings, S., Kaiser, M.J., 2006. Chronic bottom trawling alters the functional composition of benthic invertebrate communities on a sea-basin scale. Mar. Ecol. Prog. Ser. 318, 31-45.

Trimmer, M., Petersen, J., Sivyer, D.B., Mills, C., Young, E., Parker, E.R., 2005. Impact of longterm benthic trawl disturbance on sediment sorting and biogeochemistry in the southern North Sea. Mar. Ecol. Prog. Ser. 298, 79-94.

Van Nes, E.H., Amaro, T., Scheffer, M., Duineveld, G.C.A., 2007. Possible mechanisms for a marine benthic regime shift in the North Sea. Mar. Ecol. Prog. Ser. 330, 39-47.

Vander Zanden, M.J., Rasmussen, J.B., 1999. Primary consumer $\delta^{13} \mathrm{C}$ and $\delta^{15} \mathrm{~N}$ and the trophic position of aquatic consumers. Ecology 80, 1395-1404

Wada, E., 1980. Nitrogen isotope fractionation and its significance in biogeochemical processes occurring in marine environments. In: Goldberg, E.D., Horibe, Y., Saruhashi, K. (Eds.), Isotope Marine Chemistry. Uchida Rokakuho, Tokyo, pp. 375-398.

Watling, L., Findlay, R.H., Mayer, L.M., Schick, D.F., 2001. Impact of a scallop drag on the sediment chemistry, microbiota, and faunal assemblages of a shallow subtidal marine benthic community. J. Sea Res. 46, 309-324.

Wenthworth, C.K., 1922. A scale of grade and class terms for clastic sediments. J. Geol. 30 377-392.

West, G.B., Brown, J.H., 2005. Review: the origin of allometric scaling laws in biology from genomes to ecosystems: towards a quantitative unifying theory of biological structure and organization. J. Exp. Biol. 208, 1575-1592.

Wieking, G., Kröncke, I., 2003. Macrofauna communities of the Dogger Bank (central North Sea) in the late 1990s: spatial distribution, species composition and trophic structure. Helgol. Mar. Res. 57, 34-46.

Wieking, G., Kröncke, I., 2005. Is benthic trophic structure affected by food quality? The Dogger Bank example. Mar. Biol. 146, 387-400.

Wolff, W.J., 2005. The exploitation of living resources in the Dutch Wadden Sea: a historical overview. Helgol. Mar. Res. 59, 31-38.

Worm, B., Barbier, E.B., Beaumont, N., Duffy, J.E., Folke, C., Halpern, B.S., Jackson, J.B.C., Lotze, H.K., Micheli, F., Palumbi, S.R., Scala, E., Selkoe, K.A., Stachowicz, J.J., Watson, R., 2006. Impacts of biodiversity loss on ocean ecosystem services. Science 314 787-790.

Yachi, S., Loreau, M., 1999. Biodiversity and ecosystem productivity in a fluctuating environment: the insurance hypothesis. Proc. Natl. Acad. Sci. U. S. A. 96, 1463-1468

Yodzis, P., 1984. Energy flow and the vertical structure of real ecosystems. Oecologia 65 86-88. 